Jurnal ilmiah Farmasi 16(2) Agustus-Desember 2020, 130-143

ISSN: $1693-8666$

available at http://journal.uii.ac.id/index.php/JIF

\title{
Stability studies of mefenamic acid Self-Nanoemulsifying Drug Delivery System (SNEEDS) preparation with oleic acid as the oil phase
}

\section{Studi stabilitas sediaan Self Nano-Emulsifying Drug Delivery System (SNEDDS) asam mefenamat dengan asam oleat sebagai fase minyak}

\author{
Septiani Eka Cahyani, Bambang Hernawan Nugroho, Yandi Syukri*
}

Department of Pharmacy, Universitas Islam Indonesia, Jl. Kaliurang KM. 14.5 Yogyakarta 55584

*Corresponding author: yandisyukri@uii.ac.id

\begin{abstract}
Background: Mefenamic acid is a non-steroidal anti-inflammatory drug (NSAID) with low solubility in water. Self-Nanoemulsifying Drug Delivery Systems (SNEDDS) play a role to improve the solubility and bioavailability of mefenamic acid.

Objective: This study aimed to determine the stability of mefenamic acid in SNEDDS formulation through various stability studies.

Methods: The stability studies conducted consisted of centrifugation test, heating-cooling cycle test, freezethaw cycle test, robustness to dilution, accelerated storage test, and determination of drug content.

Results: The centrifugation test, heating-cooling cycle test, and freeze-thaw cycle test showed no phase separation in the samples. The robustness to dilution and accelerated storage test resulted in 2 formulas of mefenamic acid loaded SNEDDS having good stability with $10 \%$ oleic acid, $80 \%$ tween $80,10 \%$ PEG 400 and $10 \%$ oleic acid, $70 \%$ tween $80,20 \%$ PEG 400 . The determination of drug content in both of these formulations showed $98.20 \pm 0.04 \%$ and $90.98 \pm 0.06 \%$.
\end{abstract}

Conclusion: The SNEDDS formulation of mefenamic acid in this study had good stability.

Keywords: SNEDDS, mefenamic acid, stability study, oleic acid

\section{Intisari}

Latar belakang: Asam mefenamat merupakan obat anti inflamasi non steroidal (AINS) dengan kelarutan yang rendah di dalam air. Salah satu cara untuk meningkatkan kelarutan dan bioavailabilitas asam mefenamat membuatnya dalam bentuk sediaan Self Nano-Emulsifying Delivery Drug System (SNEDDS)

Tujuan: Penelitian ini bertujuan untuk menentukan stabilitas SNEDDS asam mefenamat terhadap berbagai studi stabilitas yang dilakukan

Metode: Uji stabilitas dilakukan dengan uji sentrifugasi, uji siklus panas-dingin, uji siklus beku-cair, uji ketahanan, uji penyimpanan dipercepat, dan uji kadar.

Hasil: Evaluasi uji sentrifugasi yaitu tidak terjadi pemisahan, pada uji siklus panas-dingin dan uji siklus bekucair tetap stabil dan tidak terjadi pemisahan fase. Hasil dari uji ketahanan dan uji penyimpanan dipercepat menunjukkan 2 formula SNEDDS asam mefenamat yang memiliki stabilitas yang baik dengan komponen asam oleat 10\%, tween 80 80\%, PEG $40010 \%$ dan asam oleat 10\%, tween 80 70\%, PEG $40020 \%$. Pada uji kadar diperoleh kadar asam mefenamat selama penyimpanan pada formula diatas adalah 98,20 $\pm 0,04 \%$ dan 90,98 \pm $0,06 \%$.

Kesimpulan: Dapat disimpulkan sediaan SNEDDS asam mefenamat memiliki stabilitas yang baik terhadap berbagai studi stabilitas yang dilakukan.

Kata kunci : SNEDDS, asam mefenamat, studi stabilitas, asam oleat 


\section{Pendahuluan}

Asam mefenamat merupakan obat anti inflamasi non steroidal (AINS) yang banyak digunakan oleh masyarakat. Asam mefenamat bisa digunakan untuk pengobatan sakit kepala, sakit gigi, dismenore, rheumatoid arthritis, osteoarthritis dan gangguan sendi lainnya (Sriamornsak et al., 2015).

Laju disolusi obat atau kecepatan melarut obat merupakan masalah yang sering terjadi. Asam mefenamat termasuk dalam Biopharmaceutics Classification System (BCS) kelas 2 dengan kelarutan yang rendah dan permeabilitas tinggi. Asam mefenamat memiliki bioavailibilitas yang rendah. Untuk mengatasi masalah bioavailabilitas pada obat dengan BCS kelas 2 yaitu dengan meningkatkan kelarutan dan laju disolusi obat dalam cairan lambung (Waterbeemd et al., 2009). Laju disolusi merupakan faktor penentu abrsorbsi obat pada obat-obat dengan kelarutan yang rendah (Syukri et al., 2015b). Peningkatan luas permukaan dari obat-obat dengan kelarutan rendah, misalnya karena pengurangan ukuran dalam bentuk nano dapat meningkatkan laju disolusi, yang biasa disebut nanopartikel (Ito et al., 2016).

Berdasarkan sifat kelarutan dari asam mefenamat yang rendah, bentuk sediaan Self Nanoemulsifying Drug Delivery System (SNEDDS) dipilih untuk meningkatkan bioavailibilitas oral obat-obat yang sukar larut dalam air seperti asam mefenamat (Sriamornsak et al., 2015). SNEDDS merupakan sistem penghantaran obat yang mengandung campuran minyak, surfaktan, ko-surfaktan, dan obat yang membentuk nanoemulsi secara spontan (self-emulsifying) saat dimasukkan ke dalam fase air. Hasil pencampuran sediaan SNEDDS dalam cairan lambung setelah dikonsumsi akan membentuk nanoemulsi. Bentuk nanoemulsi dipilih karena dalam nanoemulsi terdapat kandungan minyak yang dapat membawa asam mefenamat yang sukar larut dalam air. Ukuran dari SNEDDS yaitu antara 10-200 nm. Keunggulan sediaan SNEDDS adalah kemampuan membentuk nanoemulsi secara spontan di dalam saluran cerna dan ukuran tetesan yang dihasilkan berukuran nanometer. Berdasarkan penelitian sebelumnya sediaan SNEDDS memiliki stabilitas tinggi, dapat menurunkan dosis dan frekuensi dosis karena meningkatnya bioavailabilitas (Chaudhary et al., 2019).

Ukuran globul dapat mempengaruhi stabilitas sediaan emulsi. Sediaan nanoemulsi tidak menunjukkan masalah sedimentasi dan creaming, yang umumnya terjadi pada sediaan mikroemulsi. Nanoemulsi dapat stabil karena ukuran globul yang sangat kecil sehingga tidak terjadi sedimentasi dan creaming. Ukuran globul yang kecil juga dapat mencegah terjadinya flokulasi (Jaiswal et al., 2015).

Asam oleat yang memiliki HLB 17 banyak digunakan dalam sediaan emulsi seperti Self emulsifying Drug Delivery System (SEDDS), Self-Micro Emulsifying Drug Delivery System (SMEDDS), 
dan Self-Nano Emulsifying Drug Delivery System (SNEDDS). Kelarutan asam mefenamat dalam asam oleat berdasarkan data optimasi yang dilakukan peneliti lain yaitu 8,15 mg/ml (Istanti, 2016).

Penelitian ini bertujuan untuk melakukan studi stabilitas dari sediaan Self-Nanoemulsifying Drug Delivery System (SNEDDS) asam mefenamat dengan fase minyak asam oleat yang meliputi uji sentrifugasi, uji siklus panas-dingin, uji siklus beku-cair, uji ketahanan, uji penyimpanan dipercepat untuk melihat stabilitas fisik dan uji kadar untuk melihat stabilitas kimia dari sediaan SNEDDS asam mefenamat, sehingga dapat memberikan gambaran tentang formulasi yang optimal dan stabil terhadap serangkaian uji stabilitas yang dilakukan.

\section{Metodologi penelitian}

\subsection{Bahan}

Bahan yang digunakan pada penelitian yaitu asam mefenamat (PT. Chem Cross), asam oleat (PT. Menjangan Sakti), tween 80 (PT. Brataco), PEG 400 (PT. Brataco), metanol p.a. (MERCK) dan aqua pro injectio (Laboratorium Terpadu Universitas Islam Indonesia) dimana semua bahan memiliki kualitas farmasetis.

\subsection{Penentuan $\lambda$ maksimal asam mefenamat}

Penentuan $\lambda$ maksimal asam mefenamat dilakukan dengan cara ditimbang 12,5 mg asam mefenamat lalu dimasukkan ke dalam labu ukur $50 \mathrm{ml}$, kemudian dilarutkan menggunakan metanol sampai tanda batas dan diperoleh konsentrasi $250 \mathrm{ppm}$. Selanjutnya diambil 0,36 $\mathrm{ml}$ diencerkan menggunakan metanol sampai tanda batas ke dalam labu ukur $10 \mathrm{ml}$, diperoleh konsentrasi 9 ppm. Setelah itu larutan dibaca absorbansinya menggunakan spektrofotometri UV/Vis (Shimadzu UV Spechtrophotometer, $U V$-1800) pada panjang gelombang 240-340 nm dengan metanol sebagai blanko (Qamar, 2014).

\subsection{Pembuatan kurva kalibrasi asam mefenamat}

Dari larutan baku 250 ppm, dibuat seri kadar 6, 8, 10, 12, dan 14 ppm didalam labu ukur 10 ml, kemudian dilarutkan menggunakan metanol sampai tanda batas. Larutan kemudian dibaca absorbansinya (Qamar, 2014).

\subsection{Pembuatan SNEDDS asam mefenamat}

Asam mefenamat ditimbang sebanyak $50 \mathrm{mg}$ ditambahkan tween 80 sebagai surfaktan lalu disonikasi sampai homogen, kemudian ditambahkan PEG 400 sebagai ko-surfaktan lalu disonikasi kembali, dan terakhir ditambahkan asam oleat sebagai fase minyak lalu disonikasi untuk homogenisasi dan memperkecil ukuran partikel. Jumlah minyak, surfaktan, dan ko-surfaktan yang ditambahkan tergantung dari perbandingan minyak: Smix. 


\subsection{Uji sentrifugasi}

SNEDDS asam mefenamat diencerkan 100 kali menggunakan aqua pro-injectio, lalu disentrifugasi pada 3500 rpm selama 30 menit kemudian dilihat secara visual untuk pemisahan fase (Weerapol et al., 2014).

\subsection{Uji siklus-panas dingin}

Formulasi yang stabil pada uji sentrifugasi selanjutnya dilakukan uji siklus panas-dingin sebanyak enam siklus setiap 8 jam pada masing-masing suhu $4^{\circ} \mathrm{C}$ dan $40^{\circ} \mathrm{C}$ dengan penyimpanan SNEDDS asam mefenamat tidak kurang dari 48 jam. Lalu disentrifugasi pada 3500 rpm selama 15 menit dan diamati pemisahan fase yang terjadi (Syukri et al., 2018).

\subsection{Uji siklus beku-cair}

Formulasi yang stabil pada uji siklus panas-dingin selanjutnya dilakukan uji siklus beku-cair sebanyak enam siklus. SNEDDS asam mefenamat disimpan pada suhu $-20^{\circ} \mathrm{C}$ selama 8 jam untuk siklus pertama, kemudian dikeluarkan dan disimpan pada suhu $25^{\circ} \mathrm{C}$ untuk siklus kedua, ditunggu hingga mencair selama 3 menit. Selanjutnya dilajutkan siklus ke tiga sampai keenam dengan perlakuan yang sama. Lalu disentrifugasi pada $3500 \mathrm{rpm}$ selama 15 menit dan diamati pemisahan fase yang terjadi (Syukri et al., 2018).

\subsection{Uji ketahanan}

Formulasi yang stabil pada uji siklus beku-cair selanjutnya dilakukan uji ketahanan. SNEDDS asam mefenamat diencerkan 25, 50, 100, dan 250 kali, menggunakan aqua pro-injectio dan dievaluasi perubahan ukuran globul, Polydispersity index (PDI), dan \% transmitan (Weerapol et al., 2014).

\subsection{Uji penyimpanan dipercepat}

Formulasi yang stabil pada uji ketahanan selanjutnya dilakukan uji penyimpanan dipercepat selama 1 bulan dengan kondisi penyimpanan $40^{\circ} \mathrm{C} \pm 2^{\circ} \mathrm{C} / 75 \% \mathrm{RH} \pm 5 \% \mathrm{RH}$, kemudian dievaluasi ukuran partikel, PDI, dan \% transmitan pada minggu ke-0, 1, 2, 3, dan 4 pada SNEDDS asam mefenamat yang diencerkan 100 kali (Syukri et al., 2019).

\subsection{Uji kadar SNEDDS asam mefenamat}

Diambil sediaan SNEDDS asam mefenamat sebanyak 0,25 ml kemudian dilarutkan di dalam labu ukur $10 \mathrm{ml}$, diperoleh konsentrasi $250 \mathrm{ppm}$. Dari larutan baku $250 \mathrm{ppm}$, diambil 0,4 ml kemudian dimasukkan ke dalam labu ukur $10 \mathrm{ml}$ dan dilarutkan menggunakan metanol sampai tanda batas (Qamar, 2014). Larutan kemudian dibaca absorbansinya. Dihitung kadar asam mefenemat yang terkandung dalam SNEDDS. 


\subsection{Analisis hasil}

Pemisahan fase yang terjadi dapat diamati secara visual. Ukuran partikel dan PDI dari sediaan yang dihasilkan, ditentukan dengan menggunakan particle size analyser (PSA) dengan nilai ukuran partikel kurang dari $200 \mathrm{~nm}$ dan PDI 0,200-0,700. Untuk melihat nilai transmitan menggunakan spektrofotometri UV dengan nilai terbaik mendekati 100\%.

\section{Hasil dan pembahasan}

\subsection{Penetapan $\lambda$ maksimal asam mefenamat}

Panjang gelombang maksimal asam mefenamat ditetapkan berdasarkan penelitian yang dilakukan oleh Istanti (2016). Panjang gelombang maksimal asam mefenamat ditentukan menggunakan spektrofotometer UV/Vis dengan kisaran panjang gelombang 240-340 nm. Penentuan panjang gelombang maksimal digunakan untuk mengetahui daerah serapan yang dapat dihasilkan berupa nilai absorbansi dari larutan baku asam mefenamat yang dilarutkan dengan metanol. Panjang gelombang dari asam mefenamat yaitu $285 \mathrm{~nm}$ (Qamar, 2014). Hasil yang diperoleh dari pembacaan panjang gelombang yaitu 284,8 $\mathrm{nm}$. Hasil tersebut masih dapat diterima karena masuk kisaran daerah serapan maksimal.

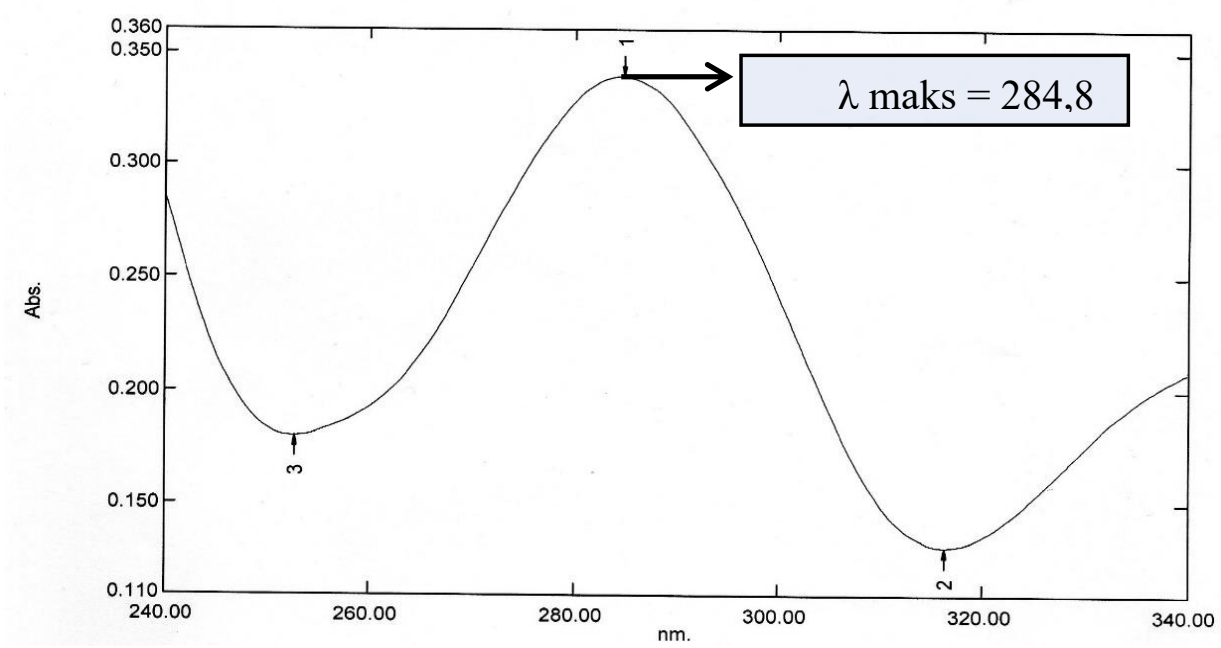

Gambar 1. Grafik panjang gelombang maksimum asam mefenamat

\subsection{Pembuatan kurva baku asam mefenamat}

Berdasarkan penelitian Istanti (2016), larutan baku asam mefenamat dianalisis pada berbagai konsentrasi dan diukur pada lamda maksimal yaitu 284,8 nm. Absorbansi dari berbagai konsesntrasi larutan kemudian diukur. Kurva baku dibuat dengan hubungan antara kadar asam mefenamat dengan serapan, lalu dibuat kurva yang merupakan hubungan antara absorbansi dan konsentrasi (Colombo et al., 2017). Berdasarkan hasil Gambar 2 diperoleh nilai r yaitu 0,9996 yang menunjukkan 
linieritas antara absorbansi dan kadar asam mefenamat dengan persamaan regresi linear $\mathrm{y}=0,2748 \mathrm{x}$ $+0,07342$.

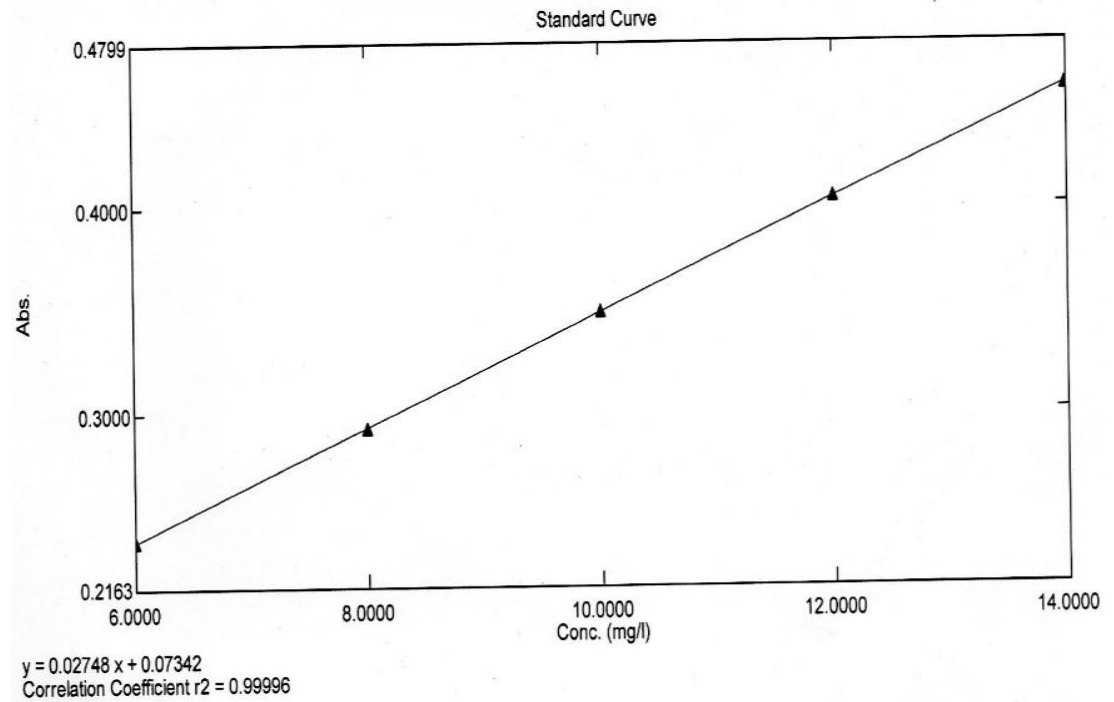

Gambar 2. Grafik kurva baku asam mefenamat

\subsection{Formulasi SNEDDS asam mefenamat}

Studi stabilitas dilakukan berdasarkan hasil optimasi formulasi SNEDDS asam mefenamat terbaik yang dilakukan oleh Istanti (2016) dengan kadar $50 \mathrm{mg} / 5 \mathrm{ml}$. Berdasarkan penelitian yang dilakukan oleh Istanti (2016) diperoleh 9 formula optimal (Tabel 1) yang kemudian akan dilakukan serangkaian studi stabilitas yang meliputi uji sentrifugasi, uji siklus panas-dingin, uji siklus-beku cair, uji ketahanan, uji penyimpanan dipercepat, dan uji kadar sediaan.

Tabel 1. Karakterisasi SNEDDS asam mefenamat $(n=3)$

\begin{tabular}{cccccccc}
\hline Minyak: Smix & $\mathbf{0}$ & $\mathbf{T}$ & $\mathbf{P}$ & $\begin{array}{c}\text { Ukuran partikel } \\
\mathbf{( n m )}\end{array}$ & PDI & $\begin{array}{c}\text { Transmitan } \\
\text { (\%) }\end{array}$ & $\begin{array}{c}\text { Zeta potensial } \\
\text { (mV) }\end{array}$ \\
\hline $1: 9$ & 10 & 80 & 10 & $188,37 \pm 5,22$ & $0,546 \pm 0,07$ & $84,65 \pm 0,005$ & $-47,43 \pm 2,61$ \\
& 10 & 70 & 20 & $198,00 \pm 1,65$ & $0,470 \pm 0,04$ & $81,56 \pm 0,002$ & $-51,57 \pm 0,55$ \\
& 10 & 60 & 30 & $344,27 \pm 31,66$ & $0,877 \pm 0,02$ & $66,17 \pm 0,006$ & $-45,63 \pm 0,68$ \\
$2: 8$ & 20 & 70 & 10 & $220,30 \pm 2,72$ & $0,545 \pm 0,04$ & $66,68 \pm 0,011$ & $-49,33 \pm 1,16$ \\
& 20 & 60 & 20 & $315,77 \pm 23,91$ & $0,463 \pm 0,06$ & $60,86 \pm 0,009$ & $-43,50 \pm 5,76$ \\
& 20 & 50 & 30 & $202,40 \pm 4,20$ & $0,564 \pm 0,04$ & $56,34 \pm 0,026$ & $-50,80 \pm 0,53$ \\
$3: 7$ & 30 & 60 & 10 & $837,50 \pm 37,62$ & $0,867 \pm 0,02$ & $47,71 \pm 0,010$ & $-55,17 \pm 1,15$ \\
& 30 & 50 & 20 & $347,73 \pm 11,65$ & $0,508 \pm 0,01$ & $41,82 \pm 0,013$ & $-59,40 \pm 5,70$ \\
& 30 & 40 & 30 & $431,03 \pm 16,25$ & $0,830 \pm 0,02$ & $9,06 \pm 0,033$ & $-44,80 \pm 0,44$ \\
\hline
\end{tabular}

Ket: $\mathrm{O}=$ asam oleat, $\mathrm{T}=$ tween $80, \mathrm{P}=\mathrm{PEG} 400$ 


\subsection{Uji sentifugasi}

Uji ini dilakukan untuk melihat fase pemisahan yang terjadi pada sampel yang telah diencerkan 100 kali yang kemudian disentrifugasi pada 3500 rpm selama 30 menit (Tabel 2). Creaming memiliki sifat reversible yaitu emulsi dapat homogen kembali setelah pengocokan (Gambar 3). Faktor-faktor yang mempengaruhi terjadinya creaming pada emulsi dapat dikaitkan dengan hukum Stokes, semakin besar perbedaan kerapatan antar fase, peningkatan terdispersi akibat flokulasi, dan peningkatan gaya gravitasi dengan sentrifugasi, akan meningkatkan kecepatan creaming. Surfaktan seringkali ditambahkan ke dalam emulsi untuk meningkatkan viskositas dan mengurangi tegangan permukaan. Creaming dapat diperlambat dengan cara meningkatkan viskositas, mengecilkan ukuran partikel, dan meningkatkan kerapatan fase minyak (Anton \& Vandamme, 2011).

Tabel 2. Hasil uji sentrifugasi

\begin{tabular}{cccclc}
\hline \multirow{2}{*}{ Minyak: Smix } & asam & tween 80 & PEG 400 & \multicolumn{2}{c}{ Pemisahan fase } \\
\cline { 5 - 6 } & oleat (\%) & (\%) & (\%) & Replikasi 1 & Replikasi 2 \\
\hline $1: 9$ & 10 & 80 & 10 & Tidak memisah & Tidak memisah \\
& 10 & 70 & 20 & Tidak memisah & Tidak memisah \\
& 10 & 60 & 30 & Tidak memisah & Tidak memisah \\
$2: 8$ & 20 & 70 & 10 & Tidak memisah & Tidak memisah \\
& 20 & 60 & 20 & Tidak memisah & Tidak memisah \\
& 20 & 50 & 30 & Tidak memisah & Tidak memisah \\
$3: 7$ & 30 & 60 & 10 & Memisah & Memisah \\
& 30 & 50 & 20 & Memisah & Memisah \\
& 30 & 40 & 30 & Memisah & Memisah \\
\hline
\end{tabular}

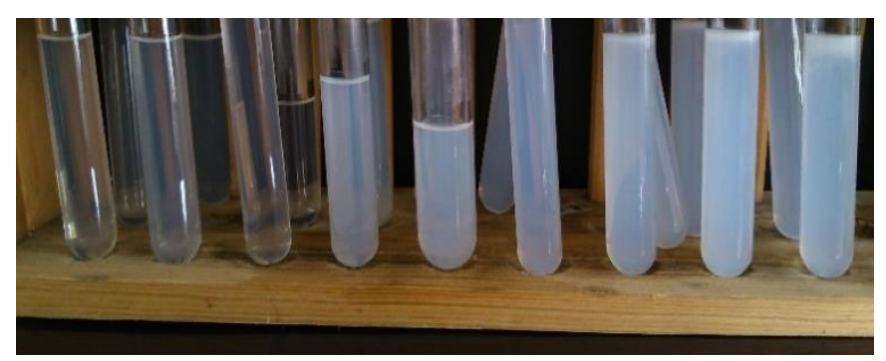

Gambar 3. Hasil uji sentrifugasi SNEDDS asam mefenamat

\subsection{Uji siklus panas-dingin}

Uji siklus panas-dingin bertujuan untuk melihat stabilitas dari SNEDDS asam mefenamat terhadap pemanasan dan pendinginan serta sentrifugasi yang diamati secara visual. Berdasarkan Tabel 3 tidak terjadi pemisahan pada formula yang diuji, dikarenakan asam mefenamat stabil pada suhu $4^{\circ} \mathrm{C}$ dan $40^{\circ} \mathrm{C}$, titik lebur dari asam mefenamat yaitu $231^{\circ} \mathrm{C}$ (Anonim, 2013b). 
Tabel 3. Hasil uji siklus panas-dingin

\begin{tabular}{cccccc}
\hline \multirow{2}{*}{ Minyak: Smix } & asam oleat & tween 80 & PEG 400 & \multicolumn{2}{c}{ Pemisahan fase } \\
\cline { 5 - 6 } & $\mathbf{( \% )}$ & $\mathbf{( \% )}$ & $\mathbf{( \% )}$ & Replikasi 1 & Replikasi 2 \\
\hline $1: 9$ & 10 & 80 & 10 & Tidak memisah & Tidak memisah \\
& 10 & 70 & 20 & Tidak memisah & Tidak memisah \\
& 10 & 60 & 30 & Tidak memisah & Tidak memisah \\
$2: 8$ & 20 & 70 & 10 & Tidak memisah & Tidak memisah \\
& 20 & 60 & 20 & Tidak memisah & Tidak memisah \\
& 20 & 50 & 30 & Tidak memisah & Tidak memisah \\
\hline
\end{tabular}

Emulsi akan stabil pada suhu $40^{\circ} \mathrm{C}-45^{\circ} \mathrm{C}$ dan tidak stabil pada suhu $50^{\circ} \mathrm{C}-65^{\circ} \mathrm{C}$ seperti yang ditunjukkan pada Gambar 4 dan Gambar 5. Emulsi akan lebih encer pada suhu tinggi dan akan mengental pada suhu rendah. Proses pembekuan lebih berpotensi dalam merusak emulsi dikarenakan kelarutan surfaktan yang lebih sensitif dalam fase minyak maupun fase air yang dapat merubah bentuk tetesan terdispersi (Anton \& Vandamme, 2011).

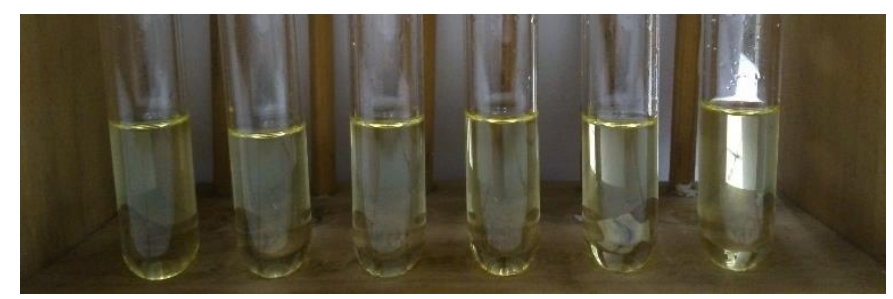

Gambar 4. SNEDDS yang di uji pada suhu $4^{\circ} \mathrm{C}$

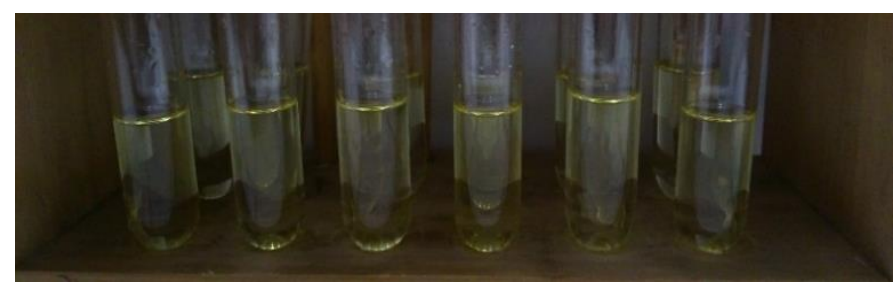

Gambar 5. SNEDDS yang di uji pada suhu $40^{\circ} \mathrm{C}$

\subsection{Uji siklus beku-cair}

Uji siklus beku-cair bertujuan untuk melihat stabilitas dari SNEDDS asam mefenamat terhadap efek pembekuan dan pencairan yang dilakukan pada suhu $-20^{\circ} \mathrm{C}$ dan $25^{\circ} \mathrm{C}$ (Gambar 6 dan Gambar 7) selama tiga siklus (Syukri et al., 2019). Berdasarkan Tabel 4 tidak terjadi pemisahan fase pada semua formulasi SNEDDS asam mefenamat.

Emulsi akan stabil pada suhu $40^{\circ} \mathrm{C}-45^{\circ} \mathrm{C}$ dan tidak stabil pada suhu $50^{\circ} \mathrm{C}-65^{\circ} \mathrm{C}$. Emulsi akan lebih encer pada suhu tinggi dan akan mengental pada suhu rendah. Proses pembekuan lebih 
berpotensi dalam merusak emulsi dikarenakan kelarutan surfaktan yang lebih sensitif dalam fase minyak maupun fase air yang dapat merubah bentuk tetesan terdispersi (Anton \& Vandamme, 2011).

Tabel 4. Hasil uji siklus beku-cair

\begin{tabular}{cccccc}
\hline \multirow{2}{*}{ Minyak: Smix } & asam oleat & tween 80 & PEG 400 & \multicolumn{2}{c}{ Pemisahan fase } \\
\cline { 5 - 6 } & (\%) & (\%) & (\%) & Replikasi 1 & Replikasi 2 \\
\hline $1: 9$ & 10 & 80 & 10 & Tidak memisah & Tidak memisah \\
& 10 & 70 & 20 & Tidak memisah & Tidak memisah \\
& 10 & 60 & 30 & Tidak memisah & Tidak memisah \\
$2: 8$ & 20 & 70 & 10 & Tidak memisah & Tidak memisah \\
& 20 & 60 & 20 & Tidak memisah & Tidak memisah \\
& 20 & 50 & 30 & Tidak memisah & Tidak memisah \\
\hline
\end{tabular}

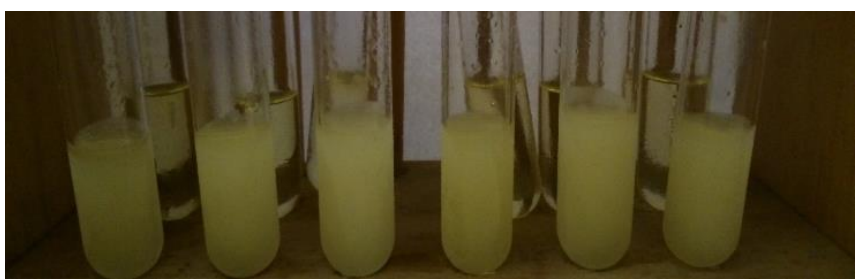

Gambar 6. SNEDDS yang diuji pada suhu $-20^{\circ} \mathrm{C}$

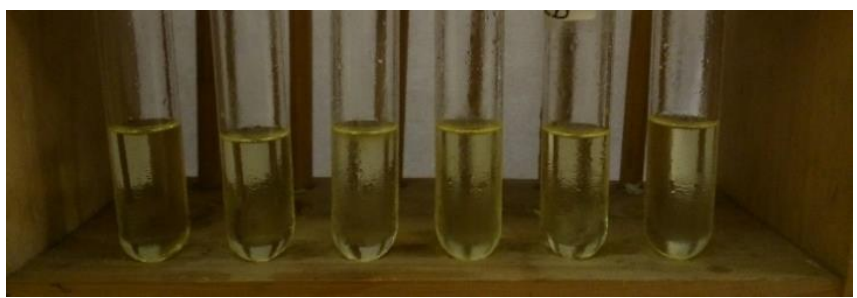

Gambar 7 SNEDDS yang diuji pada suhu $25^{\circ} \mathrm{C}$

\subsection{Uji ketahanan}

Tujuan dilakukannya uji ketahanan yaitu untuk membuktikan bahwa emulsi/nanoemulsi yang terbentuk memiliki sifat serupa dengan pengenceran yang berbeda dan untuk memastikan bahwa obat tidak akan membentuk endapan pada pengenceran yang lebih tinggi (Syukri et al., 2019). SNEDDS asam mefenamat diencerkan sebanyak 25, 50, 100, dan 250 kali kemudian dievaluasi ukuran partikel, PDI, dan \% transmitan. Pengukuran ukuran partikel dan PDI dilakukan untuk melihat stabilitas asam mefenamat terhadap variasi pengenceran. Nilai PDI menggambarkan keseragaman ukuran partikel yang terukur dari suatu emulsi. Nilai PDI yang lebih besar dari 0,4 menunjukkan bahwa distribusi ukuran partikel pada sampel semakin luas sehingga menunjukkan semakin rendahnya keseragaman partikel yang terukur (Mao et al., 2009). 
Tabel. 5. Hasil ukuran partikel dan PDI uji ketahanan $(n=3)$

\begin{tabular}{|c|c|c|c|c|c|}
\hline \multirow[t]{3}{*}{ Minyak: Smix } & \multirow{3}{*}{$\begin{array}{l}\text { Formula } \\
\text { 0: T: P }\end{array}$} & \multicolumn{4}{|c|}{ Pengenceran } \\
\hline & & \multicolumn{2}{|c|}{$25 X$} & \multicolumn{2}{|c|}{$50 X$} \\
\hline & & $\begin{array}{l}\text { Ukuran partikel } \\
\text { (nm) }\end{array}$ & PDI & $\begin{array}{c}\text { Ukuran } \\
\text { partikel }(\mathrm{nm})\end{array}$ & PDI \\
\hline \multirow[t]{3}{*}{$1: 9$} & $1: 8: 1$ & $192,87 \pm 5,40$ & $0,550 \pm 0,02$ & $192,67 \pm 3,9$ & $0,620 \pm 0,05$ \\
\hline & $1: 7: 2$ & $198,57 \pm 4,20$ & $0,564 \pm 0,02$ & $189,57 \pm 5,9$ & $0,265 \pm 0,08$ \\
\hline & $1: 6: 3$ & $206,40 \pm 4,90$ & $0,572 \pm 0,05$ & $300,67 \pm 1,6$ & $0,767 \pm 0,04$ \\
\hline \multirow[t]{3}{*}{$2: 8$} & $2: 7: 1$ & $239,13 \pm 4,90$ & $0,717 \pm 0,04$ & $197,83 \pm 6,5$ & $0,657 \pm 0,05$ \\
\hline & $2: 6: 2$ & $379,63 \pm 16,5$ & $0,643 \pm 0,06$ & $272,07 \pm 19$ & $0,563 \pm 0,00$ \\
\hline & $2: 5: 3$ & $283,27 \pm 9,94$ & $0,513 \pm 0,03$ & $299,43 \pm 28$ & $0,605 \pm 0,02$ \\
\hline \multirow[t]{2}{*}{ Minyak: Smix } & Formula & \multicolumn{2}{|c|}{ 100X } & \multicolumn{2}{|c|}{$250 X$} \\
\hline & O: T: P & $\begin{array}{c}\text { Ukuran partikel } \\
\text { (nm) }\end{array}$ & PDI & $\begin{array}{c}\text { Ukuran } \\
\text { partikel }(\mathrm{nm})\end{array}$ & PDI \\
\hline \multirow[t]{3}{*}{$1: 9$} & $1: 8: 1$ & $192,97 \pm 3,80$ & $0,598 \pm 0,07$ & $147,37 \pm 13,50$ & $0,352 \pm 0,03$ \\
\hline & $1: 7: 2$ & $195,33 \pm 7,27$ & $0,583 \pm 0,05$ & $77,63 \pm 0,55$ & $0,400 \pm 0,02$ \\
\hline & $1: 6: 3$ & $393,77 \pm 18,30$ & $0,845 \pm 0,04$ & $261,60 \pm 21,20$ & $0,538 \pm 0,08$ \\
\hline \multirow[t]{3}{*}{$2: 8$} & $2: 7: 1$ & $218,63 \pm 2,40$ & $0,765 \pm 0,03$ & $232,40 \pm 21,10$ & $0,548 \pm 0,13$ \\
\hline & $2: 6: 2$ & $298,30 \pm 23,90$ & $0,652 \pm 0,06$ & $327,13 \pm 18,70$ & $0,701 \pm 0,03$ \\
\hline & $2: 5: 3$ & $274,27 \pm 28,90$ & $0,575 \pm 0,09$ & $293,70 \pm 11,80$ & $0,519 \pm 0,04$ \\
\hline
\end{tabular}

Berdasarkan data hasil pada Tabel 5 diperoleh hasil ukuran partikel dan PDI yang stabil pada formula 1:8:1 dan 1:7:2, sedangkan hasil ukuran partikel dan PDI yang tidak stabil pada formula 1:6:3, $2: 7: 1,2: 6: 2$, dan 2:5:3. Formula SNEDDS dikatakan stabil apabila memiliki ukuran partikel kurang dari $200 \mathrm{~nm}$ dan PDI 0,20-0,70 dengan ketahanan terhadap pengaruh pengenceran (Makadia et al., 2013; Mao et al., 2009). Beberapa faktor yang mempengaruhi ukuran partikel yaitu faktor yang disebabkan oleh panas disebabkan gaya gesek dan tekanan tinggi saat proses homogenisasi. Surfaktan non ionik untuk tipe emulsi oil in water $(\mathrm{o} / \mathrm{w})$ rentan pada suhu tinggi. Ketika terjadi peningkatan suhu, bagian hidrofilik dari molekul emulsifier ini akan menjadi semakin dehidrasi sehingga menyebabkan partikel emulsi rentan terhadap koalesen dan membuat ukuran partikel emulsi menjadi lebih besar (Kassem et al., 2016).

Pada Tabel 5 nilai PDI yang terukur berkisar antara 0,3 hingga 0,8. Nilai PDI yang cukup besar ini dapat disebabkan karena kemampuan surfaktan yang tidak mampu membuat partikel yang seragam, faktor lainnya dapat disebabkan karena jenis homogenizer yang digunakan yaitu high pressure homogenizer yang merupakan jenis homogenizer yang menghasilkan nilai PDI yang cenderung lebih besar (Sriamornsak et al., 2015).

Setelah dievaluasi ukuran partikel dan PDI, selanjutnya dilakukan pengukuran \% transmitan. Nilai \% transmitan dapat menggambarkan kemampuan emulsifikasi dari surfaktan (Anton \& Vandamme, 2011). Pada Tabel 6 menunjukkan hasil bahwa semakin tinggi pengenceran, semakin tinggi nilai \% transmitan. Formula yang memiliki nilai \% transmitan yang cukup tinggi terdapat pada 
formula 1:8:1, 1:7:2, dan 1:6:3 pada pengenceran 1:250. Semakin tinggi nilai \% transmitan, semakin baik kemampuan surfaktan dalam proses emulsifikasi. Nilai \% transmitan yang diperoleh kurang dari 90\% dikarenakan larutan yang dihasilkan jernih dan sedikit bluish. Hal tersebut dikarenakan preparasi yang kurang tepat dari peneliti.

Tabel. 6. Hasil uji transmitan pada uji ketahanan (n=3)

\begin{tabular}{cccccc}
\hline \multirow{2}{*}{ Minyak: Smix } & Formula & \multicolumn{4}{c}{ Transmitan (\%) } \\
\cline { 3 - 5 } & 0: T: P & $\mathbf{1 : 2 5}$ & $\mathbf{1 : 5 0}$ & $\mathbf{1 : 1 0 0}$ & $\mathbf{1 : 2 5 0}$ \\
\cline { 3 - 5 } & $1: 8: 1$ & $28,39 \pm 0,08$ & $44,18 \pm 0,03$ & $70,53 \pm 0,01$ & $80,62 \pm 0.02$ \\
$1: 7: 2$ & $40,09 \pm 0,03$ & $67,91 \pm 0,01$ & $61,34 \pm 0,01$ & $81,69 \pm 0,01$ \\
& $1: 6: 3$ & $57,61 \pm 0,00$ & $58,86 \pm 0,01$ & $80,97 \pm 0,02$ & $91,59 \pm 0,00$ \\
\hline $2: 8$ & $2: 7: 1$ & $29,18 \pm 0,01$ & $36,15 \pm 0,01$ & $48,48 \pm 0,01$ & $61,49 \pm 0,00$ \\
& $2: 6: 2$ & $24,96 \pm 0,00$ & $41,99 \pm 0,01$ & $53,59 \pm 0,00$ & $65,69 \pm 0,01$ \\
& $2: 5: 3$ & $30,41 \pm 0,00$ & $24,26 \pm 0,01$ & $59,76 \pm 0,01$ & $35,24 \pm 0,00$ \\
\hline
\end{tabular}

Dari 6 formulasi SNEDDS, diperoleh 2 formulasi optimal yang memiliki stabilitas yang baik dilihat dari stabilitas ukuran partikel dan PDI yaitu pada formula 1:8:1 dan 1:7:2. Formulasi optimal yang diperoleh kemuadian dilakukan uji penyimpanan dipercepat selama 1 bulan untuk melihat stabilitas SNEDDS asam mefenamat pada penyimpanan dengan pengaruh suhu dan kelembaban.

\subsection{Uji penyimpanan dipercepat}

Uji ini dilakukan selama 1 bulan dengan suhu dan kelembaban yang disesuaikan $\left(40^{\circ} \mathrm{C} \pm\right.$ $2^{\circ} \mathrm{C} / 75 \% \mathrm{RH} \pm 5 \% \mathrm{RH}$ ) dengan menggunakan climatic chamber. Hasil dievaluasi pada minggu ke- 0,1 , 2, 3, dan 4 yang meliputi evaluasi ukuran partikel, PDI, dan \% transmitan. Dari pengujian ini diharapkan hasil uji penyimpanan dipercepat mendekati kriteria perubahan stabilitas yang signifikan. Hasil dari kondisi penyimpanan dipercepat dapat digunakan untuk mengevaluasi efek jangka pendek di luar kondisi penyimpanan yang tertera pada label (Anonim, 2013a).

Berdasarkan tabel 7 diperoleh ukuran partikel dan PDI yang stabil pada uji penyimpanan dipercepat. Uji dilakukan selama 1 bulan, dievaluasi pada minggu ke- 0, 1, 2, 3, dan 4. Ukuran partikel yang diperoleh kurang dari $200 \mathrm{~nm}$ dan nilai PDI 0,20-0,70, dapat dikatakan bahwa formula 1:8:1 dan 1:7:2 memiliki ukuran partikel dan PDI yang stabil terhadap penyimpanan dipercepat.

Evaluasi yang dilakukan selain ukuran partikel dan PDI yaitu evaluasi transmitan untuk melihat stabilitas formula dalam meneruskan cahaya yang ditembakkan dari spektrofotometri UV dimana nilai tersebut menggambarkan kemampuan proses emulsifikasi dari suatu surfaktan (Gupta et al., 2011). 
Tabel 7. Hasil uji stabilitas dipercepat $(n=3)$

\begin{tabular}{ccccc}
\hline Minggu ke & \multicolumn{4}{c}{ Minyak: Smix (1:9) } \\
\cline { 2 - 5 } & \multicolumn{2}{c}{$\mathbf{1 : 8 : 1}$} & \multicolumn{2}{c}{$\mathbf{1 : 7 : 2}$} \\
\cline { 2 - 5 } & $\begin{array}{c}\text { Ukuran partikel } \\
\text { (nm) }\end{array}$ & PDI & $\begin{array}{c}\text { Ukuran partikel } \\
\text { (nm) }\end{array}$ & PDI \\
\hline 0 & $86,07 \pm 11,98$ & $0,289 \pm 0,17$ & $68,30 \pm 7,16$ & $0,345 \pm 0,09$ \\
1 & $53,67 \pm 9,25$ & $0,502 \pm 0,07$ & $67,93 \pm 2,60$ & $0,510 \pm 0,01$ \\
2 & $139,5 \pm 16,67$ & $0,388 \pm 0,03$ & $142,7 \pm 6,14$ & $0,339 \pm 0,08$ \\
3 & $143,97 \pm 3,18$ & $0,377 \pm 0,04$ & $152,9 \pm 1.05$ & $0,365 \pm 0,03$ \\
4 & $167,37 \pm 14,44$ & $0,513 \pm 0,09$ & $173,07 \pm 17,34$ & $0,508 \pm 0,08$ \\
\hline
\end{tabular}

Tinggi rendahnya nilai \% transmitan yang diperoleh dapat mempengaruhi tingkat kejernihan sediaan. Berdasarkan Tabel 8 surfaktan memiliki kemampuan emulsifikasi yang cukup baik. Berdasarkan hasil evaluasi ukuran partikel, PDI, dan \% transmitan pada uji penyimpanan dipercepat selama 1 bulan diperoleh 2 formulasi stabil yaitu formula 1:8:1 dan 1:7:2.

Tabel 8. Hasil uji transmitan pada uji stabilitas dipercepat

\begin{tabular}{ccc}
\hline Minggu ke & \multicolumn{2}{c}{ Minyak: Smix (1:9) } \\
\cline { 2 - 3 } & $\mathbf{1 : 8 : 1}$ & $\mathbf{1 :} \mathbf{7 : \mathbf { 2 }}$ \\
\hline 0 & $80,16 \pm 0,003$ & $79,84 \pm 0,004$ \\
1 & $80,47 \pm 0,020$ & $75,35 \pm 0,005$ \\
2 & $83,31 \pm 0,000$ & $84,76 \pm 0,004$ \\
3 & $81,15 \pm 0,002$ & $82,48 \pm 0,004$ \\
4 & $88,42 \pm 0,000$ & $84,69 \pm 0,008$ \\
\hline
\end{tabular}

\subsection{Uji kadar SNEDDS asam mefenamat}

Pengujian ini dilakukan untuk melihat apakah kadar asam mefenamat selama penyimpanan tetap stabil. Sediaan yang sudah disimpan diukur absorbansinya pada panjang gelombang $284,8 \mathrm{~nm}$, kemudian hasil absorbansi yang diperoleh dihitung kadarnya. Hasil kadar sediaan selama penyimpanan dibandingkan dengan sediaan yang masih baru. Nilai perolehan kembali kadar yang dapat diterima adalah 90\% - 110\% (Kemenkes, 2014). Penetapan kadar secara spektrofotometri dilakukan dengan menghitung antara respon absorbansi dari seri kadar (kurva baku) menggunakan persamaan regresi linear.

Dari Tabel 9 diperoleh kadar sediaan baru pada formula 1:8:1 dan 1:7:2 adalah sebesar 49,14 \pm 0,1 mg/5 ml dan 47,27 $\pm 0,02 \mathrm{mg} / 5 \mathrm{ml}$ dengan konsentrasi (\%) 98,28 \pm 0,2 dan 94,53 \pm 0,04, sedangkan kadar sediaan lama pada formula 1:8:1 dan 1:7:2 adalah sebesar 49,10 \pm 0,02 mg/5 ml dan 45,49 \pm 0,03 mg/5 ml dengan konsentrasi (\%) 98,20 \pm 0,04 dan 90,98 \pm 0,06. 
Tabel 9. Hasil uji kadar SNEDDS asam mefenamat ( $\mathrm{N}=3)$

\begin{tabular}{ccccc}
\hline Formula & \multicolumn{4}{c}{ Minyak: Smix } \\
\cline { 2 - 5 } & \multicolumn{3}{c}{$\mathbf{1 : 8 : 1}$} & $\mathbf{1 : 7 : 2}$ \\
\cline { 2 - 5 } & Kadar (mg / 5 ml) & Konsentrasi (\%) & Kadar (mg / 5 ml) & Konsentrasi (\%) \\
\hline Baru & $49,14 \pm 0,10$ & $98,28 \pm 0,20$ & $47,27 \pm 0,02$ & $94,53 \pm 0,04$ \\
Lama & $49,10 \pm 0,02$ & $98,20 \pm 0,04$ & $45,49 \pm 0,03$ & $90,98 \pm 0,06$ \\
\hline
\end{tabular}

Berdasarkan hasil tersebut sediaan SNEDDS asam mefenamat dapat dikatakan memiliki stabilitas yang cukup baik karena hasil perolehan kembali kadar masih bisa diterima yaitu kisaran 90 - 110 \% (Syukri et al., 2015a).

\section{Kesimpulan}

Studi stabilitas yang dilakukan pada uji sentrifugasi dari 9 formulasi SNEDDS asam mefenamat diperoleh 2 formula yang memenuhi rentang kadar 90-110\%, sehingga dapat disimpulkan sediaan SNEDDS asam mefenamat memiliki stabilitas yang baik terhadap berbagai studi stabilitas yang dilakukan.

\section{Ucapan terimakasih}

Penulis mengucapkan terima kasih kepada Laboratorium Teknologi Farmasi Universitas Islam Indonesia atas fasilitas dan bantuan bahan penelitian.

\section{Daftar pustaka}

Anonim. (2013a). Asean Guideline on Stability Study of Drug Product. from asean.org

Anonim. (2013b). Material safety data sheet ibuprofen MSDS. from ScienceLab

Anton, N., \& Vandamme, T. F. (2011). Nano-emulsions and micro-emulsions: clarifications of the critical differences. Pharm Res, 28(5), 978-985. doi:10.1007/s11095-010-0309-1

Chaudhary, S., Aqil, M., Sultana, Y., \& Kalam, M. A. (2019). Self-nanoemulsifying drug delivery system of nabumetone improved its oral bioavailability and anti-inflammatory effects in rat model. Journal of Drug Delivery Science and Technology, 51, 736-745. doi:https://doi.org/10.1016/j.jddst.2018.04.009

Colombo, M., Melchiades, G. L., Figueiro, F., Battastini, A. M. O., Teixeira, H. F., \& Koester, L. S. (2017). Validation of an HPLC-UV method for analysis of Kaempferol-loaded nanoemulsion and its application to in vitro and in vivo tests. J Pharm Biomed Anal, 145, 831-837. doi:10.1016/j.jpba.2017.07.046

Gupta, S., Chavhan, S., \& Sawant, K. K. (2011). Self-nanoemulsifying drug delivery system for adefovir dipivoxil: Design, characterization, in vitro and ex vivo evaluation. Colloids and Surfaces A: $\begin{array}{llll}\text { Physicochemical and Engineering } & \text { Aspects, 392(1), }\end{array}$ doi:https://doi.org/10.1016/i.colsurfa.2011.09.048

Istanti. (2016). Preparasi dan karakterisasi sediaan SNEDDS asam mefenamat dengan fase minyak asam oleat. (PharmB). Universitas Islam Indonesia, Yogyakarta.

Ito, A., Konnerth, C., Schmidt, J., \& Peukert, W. (2016). Effect of polymer species and concentration on the production of mefenamic acid nanoparticles by media milling. European Journal of 
$\begin{array}{llll}\text { Pharmaceutics } \quad \text { and } \quad \text { Biopharmaceutics, } & \text { 98, }\end{array}$ doi:https://doi.org/10.1016/j.ejpb.2015.11.011

Jaiswal, M., Dudhe, R., \& Sharma, P. K. (2015). Nanoemulsion: an advanced mode of drug delivery system. 3 Biotech, 5(2), 123-127. doi:10.1007/s13205-014-0214-0

Kassem, A. A., Mohsen, A. M., Ahmed, R. S., \& Essam, T. M. (2016). Self-nanoemulsifying drug delivery system (SNEDDS) with enhanced solubilization of nystatin for treatment of oral candidiasis: Design, optimization, in vitro and in vivo evaluation. Journal of Molecular Liquids, 218, 219232. doi:https://doi.org/10.1016/i.molliq.2016.02.081

Kemenkes. (2014). Farmakope Indonesia. Jakarta: Kemenkes RI

Makadia, H. A., Bhatt, A. Y., Parmar, R. B., Paun, J. S., \& Tank, H. M. (2013). Self-nano Emulsifying Drug Delivery System (SNEDDS): Future Aspects. Asian J Pharm Res, 3(1), 7.

Mao, L., Yang, J., Yuan, F., Gao, Y., \& Zhao, J. (2009). Effects of Small and Large Molecule Emulsifiers on the Characteristics of b-Carotene Nanoemulsions Prepared by High Pressure Homogenization. Food Technology and Biotechnology, 47.

Qamar, F. (2014). Simple UV spectrophotometric assay of Mefenamic acid.

Sriamornsak, P., Limmatvapirat, S., Piriyaprasarth, S., Mansukmanee, P., \& Huang, Z. (2015). A new self-emulsifying formulation of mefenamic acid with enhanced drug dissolution. Asian Journal of Pharmaceutical Sciences, 10(2), 121-127. doi:https://doi.org/10.1016/j.ajps.2014.10.003

Syukri, Y., Fernenda, L., Utami, F., Qiftayati, I., Kusuma, A., \& Istikaharah, R. (2015a). Preperation and characterization of $\beta$-cyclodextrin inclusion complexes oral tablets containing poorly water soluble glimipiride using freeze drying method. Indonesian Journal of Pharmacy, 26, 71. doi:10.14499/indonesianjpharm26iss2pp71

Syukri, Y., Fitriani, H., Pandapotan, H., \& Nugroho, B. (2019). Formulation, Characterization and Stability of Ibuprofen-Loaded Self-Nano Emulsifying Drug Delivery System (SNEDDS). $\begin{array}{lllll}\text { INDONESIAN JOURNAL OF } & \text { PHARMACY, } & 30, & 105 .\end{array}$ doi:10.14499/indonesianjpharm30iss2pp105-113

Syukri, Y., Martien, R., Lukitaningsih, E., \& Nugroho, A. E. (2018). Novel Self-Nano Emulsifying Drug Delivery System (SNEDDS) of andrographolide isolated from Andrographis paniculata Nees: Characterization, in-vitro and in-vivo assessment. Journal of Drug Delivery Science and Technology, 47, 514-520. doi:https://doi.org/10.1016/j.jddst.2018.06.014

Syukri, Y., Nugroho, A., Martien, R., \& Lukitaningsih, E. (2015b). Validasi Penetapan Kadar Isolat Andrografolid dari Tanaman Sambiloto (Andrographis paniculata Nees) Menggunakan HPLC. Jurnal Sains Farmasi \& Klinis, 2, 8-14. doi:10.29208/jsfk.2015.2.1.42

Waterbeemd, H. V. D., Testa, B., Mannhold, R., Kubinyi, H., \& Folkers, G. (2009). Drug Bioavailability: Estimation of Solubility, Permeability, Absorption and Bioavailability (2nd ed.).

Weerapol, Y., Limmatvapirat, S., Nunthanid, J., \& Sriamornsak, P. (2014). Self-nanoemulsifying drug delivery system of nifedipine: impact of hydrophilic-lipophilic balance and molecular structure of mixed surfactants. AAPS PharmSciTech, 15(2), 456-464. doi:10.1208/s12249014-0078-y 